\author{
SŁAWOMIRA ŻERAŃSKA-KOMINEK \\ https://orcid.org/0000-0002-9329-1446 \\ Institute of Musicology, Faculty of History, University of Warsaw
}

\title{
Poetic Images of Nightingale in the Art Song. On Some Aspects of Musical Meaning
}

\begin{abstract}
Birds are not only part of nature, but also an important element of culture. The life and behaviour of some bird species has been reflected in literary tradition in the form of poetic images and representations reflecting existential problems and stereotypically associated with specific states of the human psyche. These images and their poetics inspired composers of the Romantic era to create their musical, semantically charged counterparts. A special place in European poetry and music is occupied by the nightingale, which has wide symbolic connotations. My article discusses the musical replicas of the nightingale's poetic representations in the songs of F. Liszt, J. Brahms, F. Schubert and K. Szymanowski. Each of the presented songs constructs meaning and relates to the poetic images in a different manner, despite the suggested or even expected repeatable nature of the emotional expression and experience symbolically associated with this bird.
\end{abstract}

KEYWORDS: Lied, nightingale, musical meaning, birds in music

To Professor Mieczystaw Tomaszewski, the first researcher of the art song in Poland

\section{Introduction}

From times immemorial birds have been an object of fascination and at the same time proof of the infinite wealth of human imagination, working in strict relation to the phenomena of nature. Symbolically set in various roles, birds contributed to magical thinking, inspired art and literature in nearly all human cultures. Birds play an immense role in the soundscape of nature, since all of them communicate using acoustic signals, and almost half of them are songbirds (Oscines). They produce an immense variety of different sounds, including long and complex vocalisations which can be described as 'songs' and which count among nature's most beautiful and complex melodies. These melodies demonstrate a remarkable and as yet not fully explained similarity to music. They vary in their ambitus and melodic contours, in tempi, rhythms and dynamics. They contain 
distinct elements of tonal organisation and are intensely expressive. According to Charles Darwin, the musical activity of birds exceeds the limits of mere biological adaptation and suggests that birds may possess an aesthetic sense. This view was shared by British ornithologist Edward A. Armstrong, who asked with disbelief in 1963: 'Does all this complexity serve merely utilitarian ends? Are birds insensitive to the beauty which we find in their songs?' (Armstrong, 1963, p. 231). Nevertheless, contemporary ornithological research, here represented by Clive Catchpole and Peter Slater book (1995), has unequivocally excluded the possibility of birdsong having any autotelic quality or, even more, any kind of 'artistic' motivation. Birdsong is strictly functional and aims to maximise the chances for survival in the given environment. What is undoubtable, however, is the aesthetic character of our own human reception of birdsong, though, contrary to appearances, it is not an easy object of auditory experience. Some frequencies of sound used in birdsong fall outside the human hearing range, and birdsong also includes noises of indefinite pitch. The very fast tempi also make it difficult if not impossible to follow the structures of birds' vocal performances.

Listening to birds is therefore most likely a complex cognitive process that involves multisensory experience as well as a rather wide variety of subtle semantic associations, which most likely constituted the main factor of the musical and conceptual idealisation of birdsong in the European tradition. At this point, one should mention the use of birdsong stylisations to represent love, closeness to nature and innocence. One of the best known, almost iconic examples of such ideational stylisations is Almirena's aria Augelletti, che cantate from G. F. Handel's opera Rinaldo.

Admittedly, the proper appreciation of the artistic values of birdsong in European culture is a relatively late phenomenon. Ancient Greek and Roman literature only contains a few mentions of birdsong, apart from a longer section in Pliny the Elder's Natural History (Ed. 1967, vol. III, p. 344-47) dedicated to the nightingale. It was only in the late Middle Ages that responses to the experience of birdsong appeared in the poems of Walther von der Vogelweide, the troubadours, Dante, Dafydd ap Gwilym, Geoffrey Chaucer, and others. The first reflections of birdsong in music are also relatively late. But from the 13th-century canon Sumer is icumen in to the works of Olivier Messiaen, birds have continually been present in music. Olivier Messiaen undoubtedly holds a special place in Europe's tradition of birdsong-inspired music. For him, birds were 'the greatest musicians that have ever lived on our planet,' and his music is imbued with elements of birdsong. However, his cycles of Réveil des oiseaux for piano and orchestra (1953), Oiseaux exotiques for piano and small orchestra (1955), and Catalogue d'Oiseaux (Catalogue of Birds) for piano solo (1956-1970) are not stereotypical stylisations of birds' voices, but rather their detailed transcriptions, both precise and creative. Messiaen's artistic transcriptions of birdsong not only have a unique emotional climate and tone-colours, but also determine the structure and architecture of these works.

The numerous imitations are not the only forms of birds' presence in music. Birds also appear in the poetic texts, for which the art song or Lied are a vehicle of expression. Such songs frequently give up even the most sophisticated forms 
of sound imitation in favour of poetic representation of symbolic meanings and connotations related to the given bird species. In the history of humankind such representations have taken shape in the cognitive process of metaphorisation, which ever since the Late Stone Age or even earlier has helped people conceptualise reality (Kövecses, 2005, p. 24). It was described in essence by Claude Lévi-Strauss, who in his La Pensée Sauvage (The Savage Mind) and Totemism (Lévi-Strauss, 1962; Lévi-Strauss, 1991) claimed that birds are perceived as topically relevant to the human community, because their lives resemble in many respects those of humans. Birds love freedom; they build themselves places to live in with their families, to feed and bring up their young; they frequently maintain social relations with other representatives of their species, communicating with them by means of acoustic signals that sound like articulate speech. To the human imagination, therefore, birds are in a sense a kind of persons, which creates a metaphoric relation between them and people. Reference to a different field of experience - namely, to the observation of birds' lives - facilitated the conceptualisation of various aspects of human social and spiritual experience in the early stages of our cultural evolution. In other words, birds as a source field for metaphoric projection provided models for the explanation of phenomena that took place in the human world.

Birds are universally presented as humans, in both the spiritual and physical dimensions. Such representations appear in all the human cultures known to us, notwithstanding the enormous wealth and diversity of bird species in the world's ecosystems and the great variety of ideas related to them. This metaphoric correlation between humans and birds is mainly explored in two spheres: that of the ability to fly through the air, and of song, whose much admired aesthetic qualities transcend the laws of nature to become a recognisable value in culture. Flight is a symbolic fulfilment of the dream of freedom and of journeys to other worlds (Eliade, 1964, pp. 477-480), while birdsong relates in a curiously intimate way to human emotionality. Not only does it exhibit numerous structural and expressive analogies to music, but also, perhaps more importantly, it generates a similar level of involvement and has a similarly strong emotional impact. Birdsong is thus crucial to the perception of the existential community of birds and men. In this context musicologists are familiar with the example of the Kaluli people from Papua New Guinea described by Steven Feld, whose links to the life of birds are wide and many (Feld, 1990).

Of the great number of bird species, some have been particularly distinguished and carefully observed by humans in their natural habitats. Their appearance, life and habits have become the subject of legends and myths passed on from one generation to another. Though these stories have been transformed, purified and re-evaluated, they have still preserved their identifiable semantic structures which are the source of symbolic representations of birds in all the later poetic-literary works. In the European cultural tradition, probably the most famous bird is the nightingale, whose myth has inspired the imagination of European artists, composers and poets from Homer to T.S. Eliot. In The Odyssey, Homer quotes the tale of Aedon, daughter of Pandareus of Ephesus and wife of Zethus, joint king of Thebes. Aedon only had one son, and, envied Niobe her 
sister-in-law, who had many. She attempted to kill Niobe's eldest son Amaleus, but ended up killing her own son Itylus by mistake. Seeing her unbearable suffering, the gods took pity on her and changed her into a nightingale, which is called Aedon in Greek. The bird, forever disconsolate because of being separated from the child, laments its loss in song. Another Greek variant of this bloody tale is best known from the partly preserved tragedy Tereus by Sophocles, while the main Latin-language version is that by Ovid, which in turn inspired many later poets, including Chrétien de Troyes, Chaucer, Gower, and Gascoigne.

Penelope compares her own sorrow and pain caused by separation from her beloved Odysseus with the despair of Aedon turned into a nightingale, lamenting the death of Itylus:

\begin{abstract}
But to me has a god given sorrow that is beyond all measure, for day by day I find my joy in mourning and lamenting, while looking to my household tasks and those of my women in the house, but when night comes and sleep lays hold of all, I lie upon my bed, and sharp cares, crowding close about my throbbing heart, disquiet me, as I mourn. Even as when the daughter of Pandareus, the nightingale of the greenwood, sings sweetly, when spring is newly come, as she sits perched amid the thick leafage of the trees, and with many trilling notes pours forth her rich voice in wailing for her child, dear Itylus, whom she had one day slain with the sword unwittingly, Itylus, the son of king Zethus (Book 19, pp. 508-553).
\end{abstract}

This tale, first presented in The Odyssey, opens the history of the poetic reception of the myth. The nightingale's song becomes identified with human crying and tears. Aedon laments, hidden among the lush vegetation on a moonlit summer's night. Her song emanates lyricism; it is an expression of despair, separation, abandonment, and the sense of imminent death. It also recollects an unfulfilled, thwarted love, now lost forever and eternally bemoaned. In the poetry of the troubadours, the nightingale symbolised the poet who died for his beloved. Its song becomes the model of truly spiritual art and artistic skill. Death, love and poetry fuse in the poetic imagination into one motif which returns in European literature in countless variants, shades and colours, invariably associated with existential pain, solitude, sorrow and longing, in most cases - contrasted with nature waking up to life in the spring.

The poetic image of the nightingale and its dirge, enhanced by the Greek myth, was elaborated upon most frequently, though naturally not exclusively, in the art songs or Lieder written by composers of the Romantic Lied.

\title{
Johannes Brahms, Der Tod das ist die kühle Nacht
}

The myth of Aedon, daughter of Pandareus is one of the darkest tales of classical Greek literature, and its rendering by Heinrich Heine in his poem of $1826 / 7$ is equally sombre. It was complemented and deepened by Brahms in his profoundly tragic song Der Tod das ist die kühle Nacht: 
Der Tod das ist die kühle Nacht, Das Leben ist der schwüle Tag. Es dunkelt schon, mich schläfert, Der Tag hat mich müd gemacht.

Über mein Bett erhebt sich ein Baum, Drin singt die junge Nachtigall;

Sie singt von lauter Liebe, Ich hör es sogar im Traum.
Our death is in the cool of night, Our life is in the pool of day. The darkness glows, I'm drowning, Day's tired me with light.

Over my head in leaves grown deep, Sings the young nightingale. It only sings of love there, I hear it in my sleep.

Brahms's song opens with two mutually complementary clauses which are devoid of drama and presented in piano dynamics, in a nearly indifferent manner, as though they expressed something obvious. (Example 1) The peace, however, is illusory. Though the $\mathrm{C}$ major key does speak in favour of life and the light of day on the words Das Leben ist der schwüle Tag, the note of F sharp that resounds in the first sentence, Der Tod das ist die kühle Nacht, introduces harmonic unrest and tension, emphasised here by the rhythm of a 'funeral march' heard in the piano accompaniment.
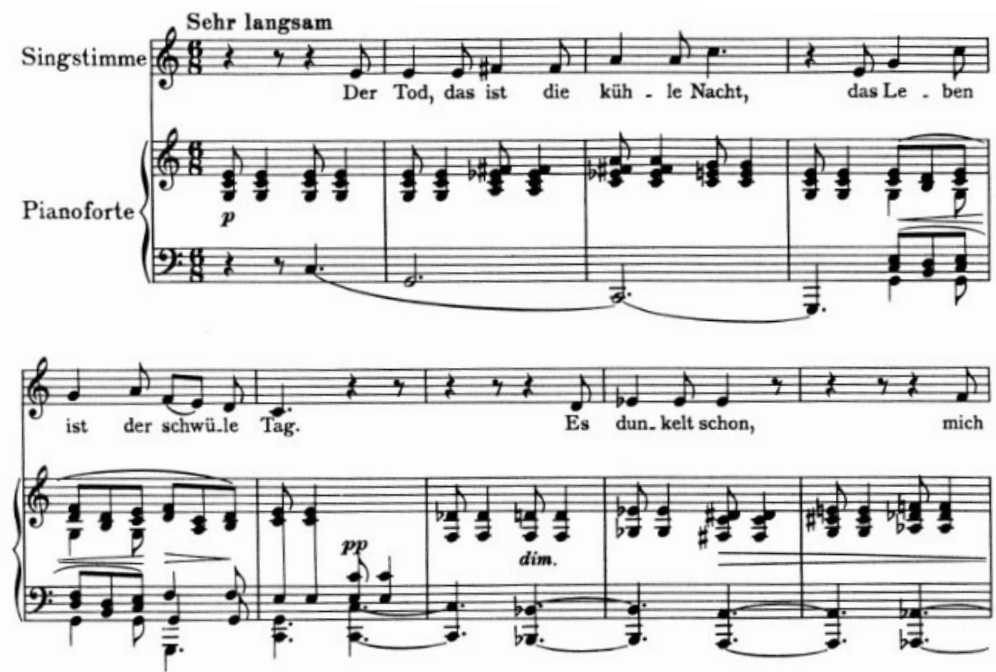

Example 1

The brief chromatic motifs of the vocal line on the words Es dunkelt schon, 'it is already getting dark,' and mich schläfert, 'I am falling asleep,' are accompanied by a descending octave progression which can be taken as a metaphor of dying. (Example 2) The twice repeated note of D on the words Der Tag in the sentence Der Tag hat mich müd gemacht, 'the day has made me tired,' sounds distinctly like the last cry before death. The poet now moves his narration into a different reality, experienced after crossing the boundary of death. I am dead and I lie on my death bed, with a tree rising above me, Über mein Bett erhebt sich ein Baum, and in the tree a young nightingale sings of love: Drin singt die junge Nachtigall 
/ Sie singt von lauter Liebe. (Example 3) The accompaniment complements this narration by imitating the bird's song with arpeggiated chords in the right hand and broken chords in the left hand. This representation of the nightingale's song is slowed down and unreal in a way, transformed by the perception of the lyrical 'I' who now dreams the eternal dream. The nightingale's song is directed toward the world of darkness and death: Ich hör es sogar im Traum. The song ends with a unreal 'funeral march' motif played with diminuendo dynamics, which signifies closure (closing the coffin?), end, and eternal silence: (Example 4)

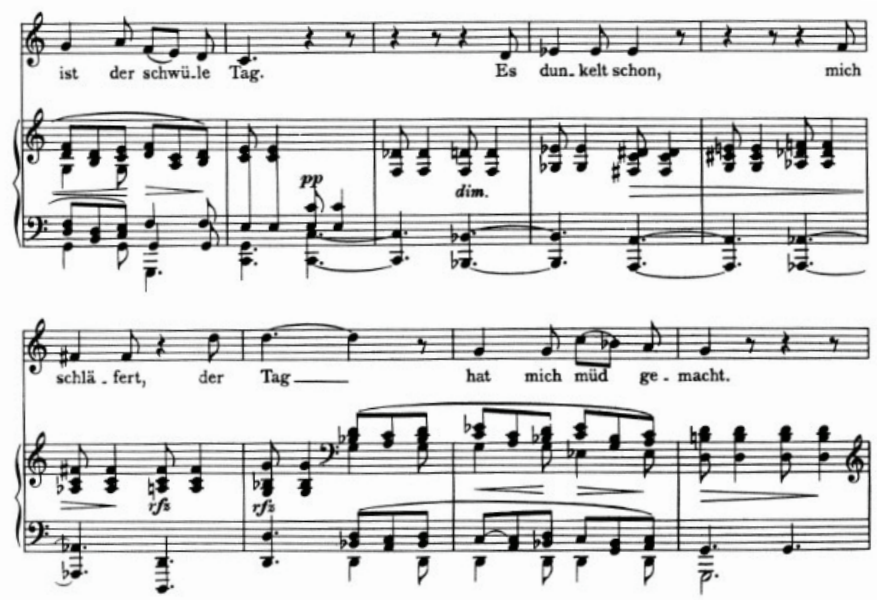

Example 2

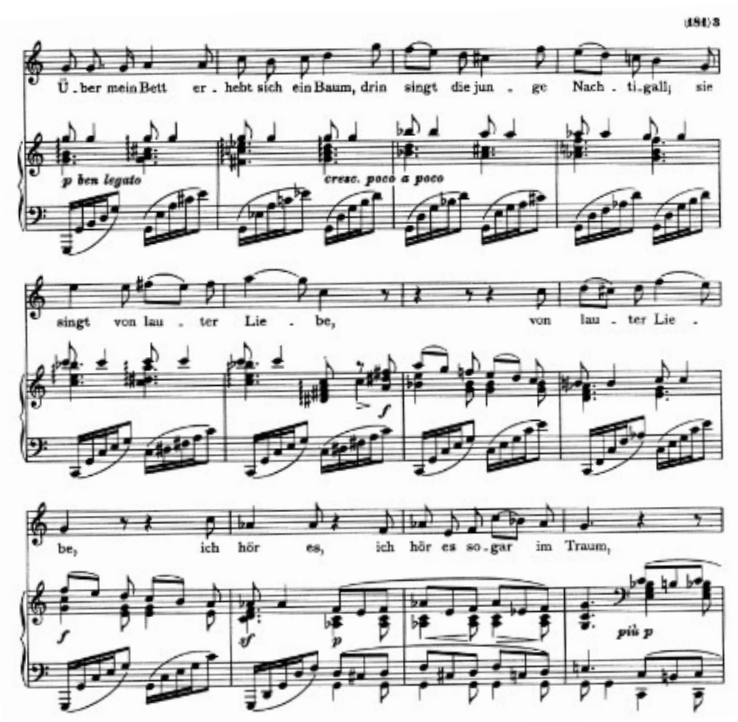

Example 3 


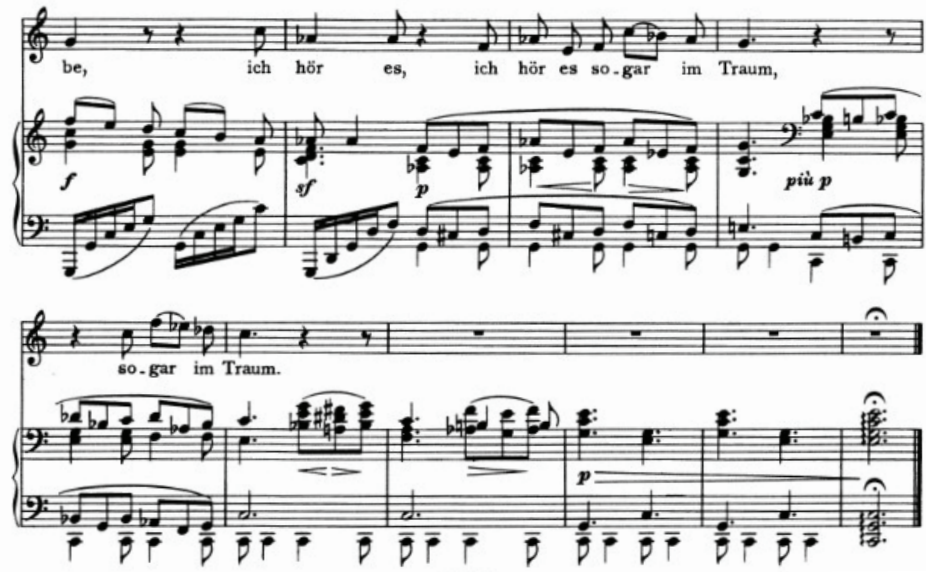

Example 4

Brahms's song Der Tod das ist die kühle Nacht, highly respectful toward Heine's text, exemplifies a profoundly harmonious type of relation between text and music, which mutually complement each other and form one whole, consistent in terms of expression. The musical representation is a metaphor of the lyrical 'I's emotions and experiences that are the content of the poem.

\section{Ferenc Liszt, Die tote Nachtigall}

The text-music relation is quite different in Ferenc Liszt's Die tote Nachtigall to words by (Johann) Philipp Kaufmann (1802-1846), a song that exists in two versions separated by the distance of 35 years (the first was written in 1844 , the second - in 1879).

Du arme, kleine Nachtigall!

Du solltest den Frühling wecken mit deinem holden, süßen Schall, und nun muß dich die Erde decken!

Dein Mütterlein sucht bang sein Kind, wie fehlst du im Kreis der Kleinen! Es weint sich fast die Augen blind, wie traurig, ach! Das ist zum weinen.

Und wenn der Frühling nun erwacht mit seiner Nachtigallen Lieder, Dann schläfst du still in Grabes Nacht, und ach! kein Ruf erweckt dich wieder.
You poor little nightingale!

You were to awaken Spring

With your lovely, sweet sound,

And now the earth must cover you!

Your mother anxiously searches for her child, Howshemissesyouinthecircleofthelittleones! She is almost blinded by her tears, How sad, ah! It is to weep.

And when Springtime now awakes With all its nightingale songs, Then you shall be sleeping quietly in the night of the grave, And, ah! no call shall awaken you again. 
The fundamental difference in the relation of music to text in Brahms's and Liszt's nightingale songs results from the different perspective of the lyrical 'I' respectively in Heine and Kaufmann's poems. The depth of personal experience in Heine's text is replaced in Kaufmann's verses by an external commentator who presents a kind of sympathetic epitaph for the dead bird. The speaker extols the beauty of its voice and its great merits for the springtime revival of life. The lyrical 'I' sympathises with the pain of the mother, to whom he can offer no consolation. Life must go on, and the new spring will come with the song of many nightingales, even though that most beloved one will never wake again.

Liszt's song explores the opposition between the sweetness of the nightingale's song and the despair caused by its loss. The topics of death, sadness and abandonment recur regularly after each return of the nightingale's melody, which is also imbued with sadness (written in the key of $\mathrm{F}$ sharp minor) and in its successive versions it undergoes chromatic deformations, which symbolise imminent death. The whole song consists of eight segments, alternating in their expressive and emotional character. The stanzaic structure of the poem is broken up and the song is largely through-composed. Thus, after an eight-measure piano introduction, in which a progression of diminished chords leads the listener into the underworld (Example 5) the composer brings in the nightingale's song on the words Du arme, kleine Nachtigall! Du solltest den Frühling wecken mit deinem holden, süßen Schall (Example 6) and ends this strain of musical thought with the death motif on und nun mu $\beta$ dich die Erde decken! (Example 7).

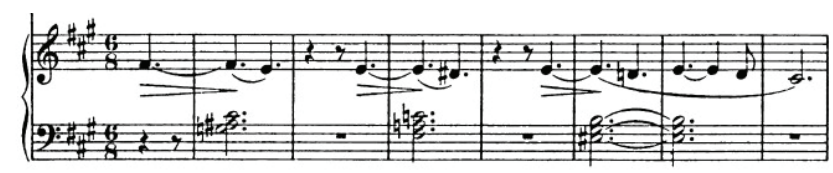

Example 5
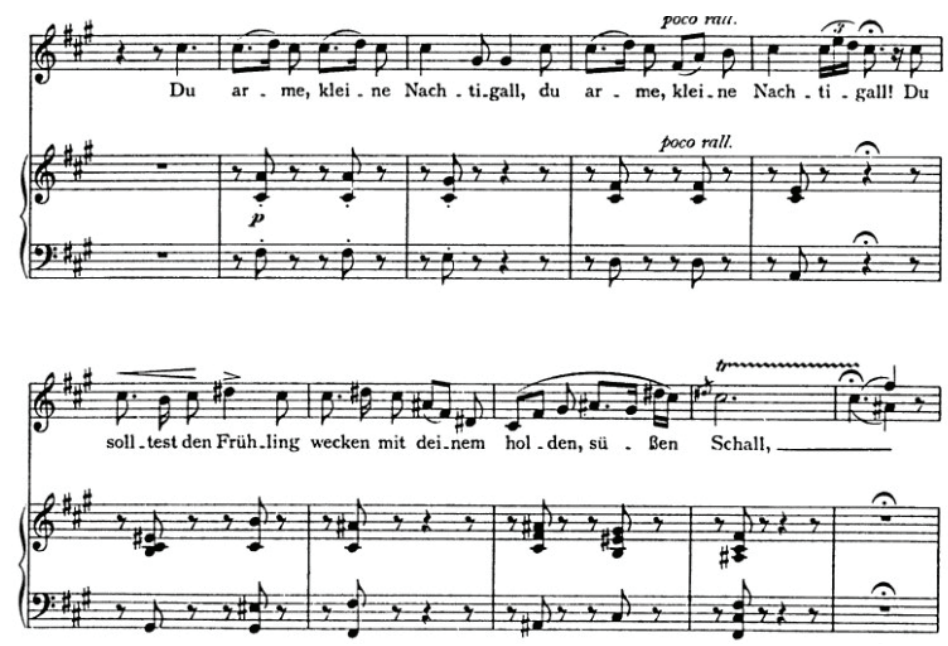

Example 6 


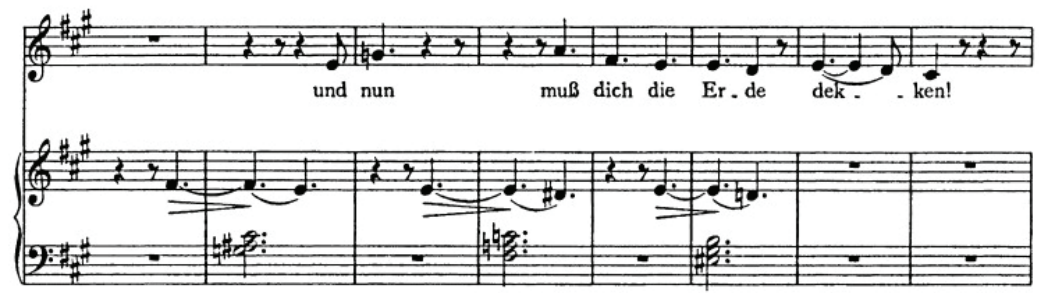

Example 7

In segment four, the chromatically tinged melody of the nightingale on Dein Mütterlein sucht bang sein Kind, wie fehlst du im Kreis der Kleinen! Es weint sich fast die Augen blind, wie traurig, ah! (Example 8) ends with the sound of the despairing mother's crying or weeping: Das ist zum weinen, without any accompaniment. (Example 9) The cheerful and richly ornamented song of many nightingales heralds a new spring in a major key and forte dynamics (Example 10) after which the words of mourning and the dirge, descending melody return on Dann schläfst du still in Grabes Nacht. (Example 11)

The nightingale's last moments are represented in the last, eighth segment by the nightingale melody in minor which now slows down and dies away. The whole ends with chords separated by long rests, which, along with the words und ach! kein Ruf erweckt dich wieder, announce the approaching silence of eternity. (Example 12)
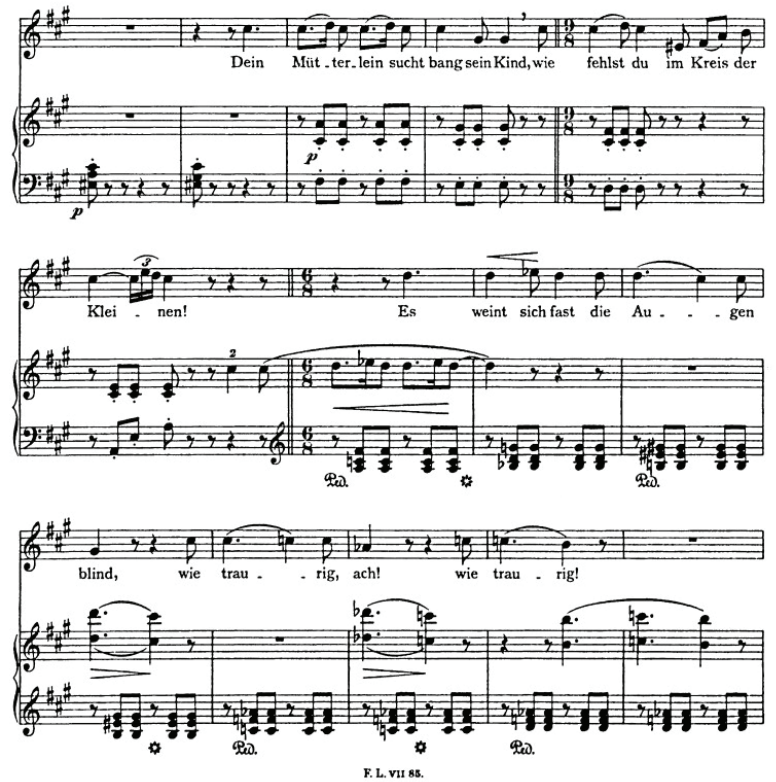

Example 8 


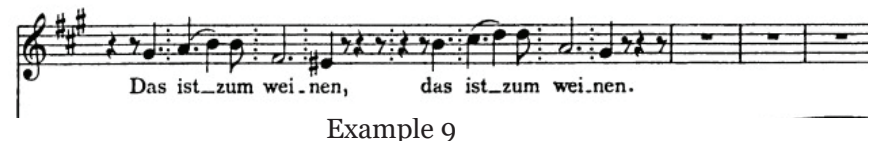

Example 9
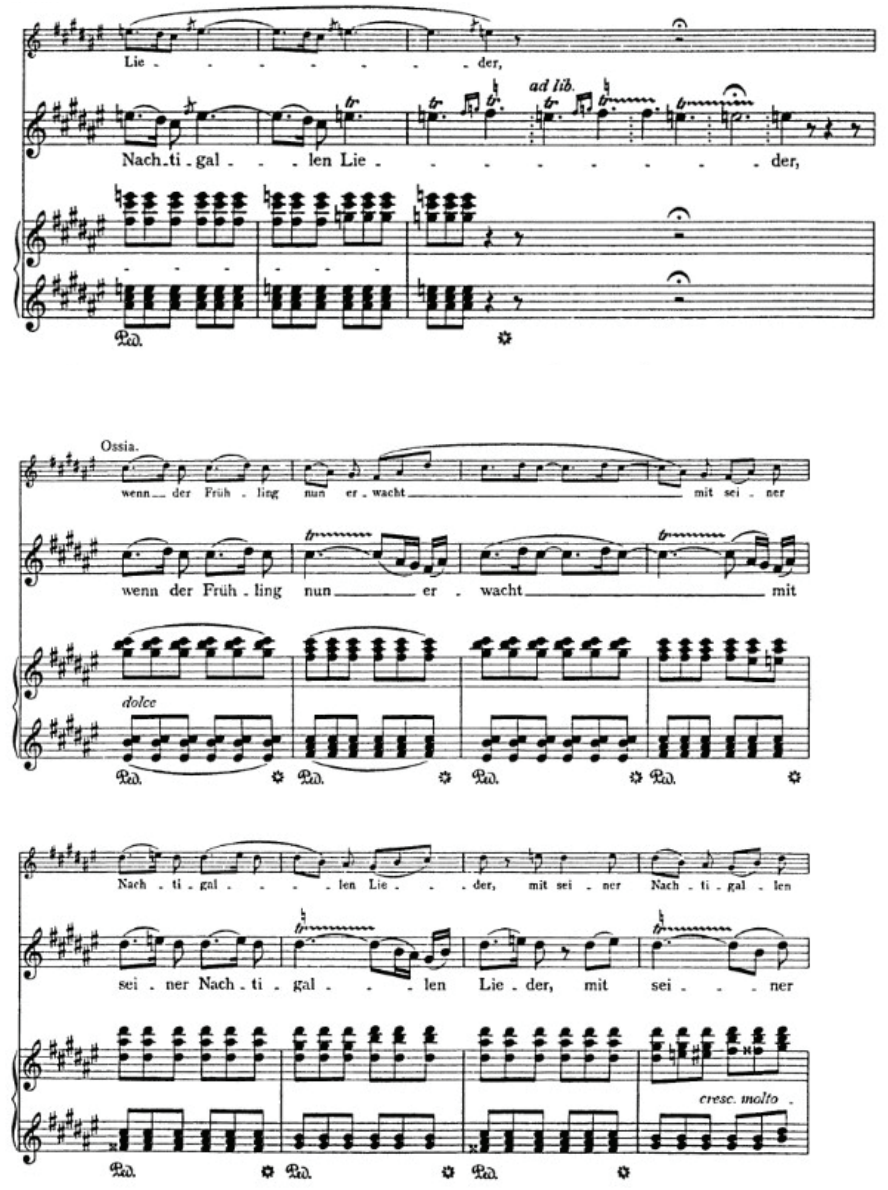

Example 10

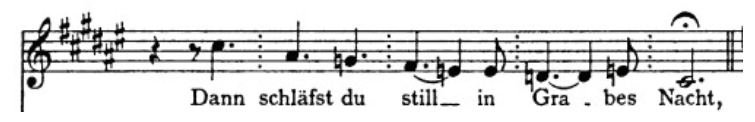




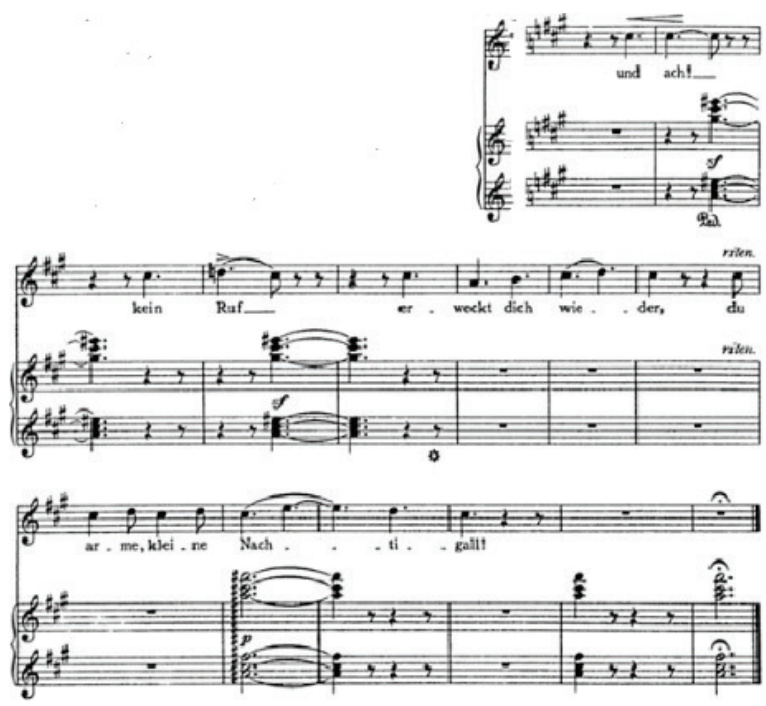

Example 12

\section{Franz Schubert, An die Nachtigall}

Brahms's and Liszt's poetic-musical reflections on life and death have different character and undertones from Schubert's setting of Ludwig Christoph Hölty's poem An die Nachtigall, the third song from Op. 172, composed in 1815.

GeußnichtsolautderliebentflammtenLieder Tonreichen Schall

Vom Blütenast des Apfelbaums hernieder, O Nachtigall!

Du tönest mir mit deiner süßen Kehle Die Liebe wach;

DennschondurchbebtdieTiefenmeinerSeele Dein schmelzend Ach.

DannfliehtderSchlafvonneuemdiesesLager, Ich starre dann

Mit nassem Blick' und totenbleich und hager Den Himmel an.

Fleuch, Nachtigall, in grüne Finsternisse, Ins Haingesträuch,

Und spend' im Nest der treuen Gattin

Do not pour so loudly the full-throated sounds Küsse; Entfleuch, entfleuch!
Of your love-kindled songs

Down from the blossoming boughs of the apple-tree, O nightingale!

The tones of your sweet throat Awaken love in me;

For the depths of my soul already quiver With your melting lament.

Sleep once more forsakes this couch, And I stare

Moist-eyed, haggard and deathly pale At the heavens.

Fly, nightingale, to the green darkness, To the bushes of the grove, And there in the nest kiss your faithful mate; Fly away, fly away! 
This text poetically exploits all the elements of the nightingale myth: the bird's lament, the tree in which his spouse has her nest, the paleness of death, as well as lost or tragic love. The words directed to the nightingale can be summarised in two sentences: 'Your song kindles love in my heart and stops me from sleeping!' and 'Stop singing, fly away!' That former sentence - a confession of the speaker's feelings and the impact of the nightingale's song - summarises the content of stanzas two and three, whereas the second sentence, a request or demand directed to the bird, is elaborated upon in stanzas one and four. One could therefore expect the melody of stanza one to be repeated in stanza four, and the lyrical melody of stanza two - in stanza three. However, unlike Brahms and Liszt in the previously analysed songs, Schubert did not envisage a semiotic amalgam of text and music, but made his musical setting independent of textual structure by juxtaposing - seemingly at odds with the contents of the poem - two expressively contrasted musical sections. (Example 13)

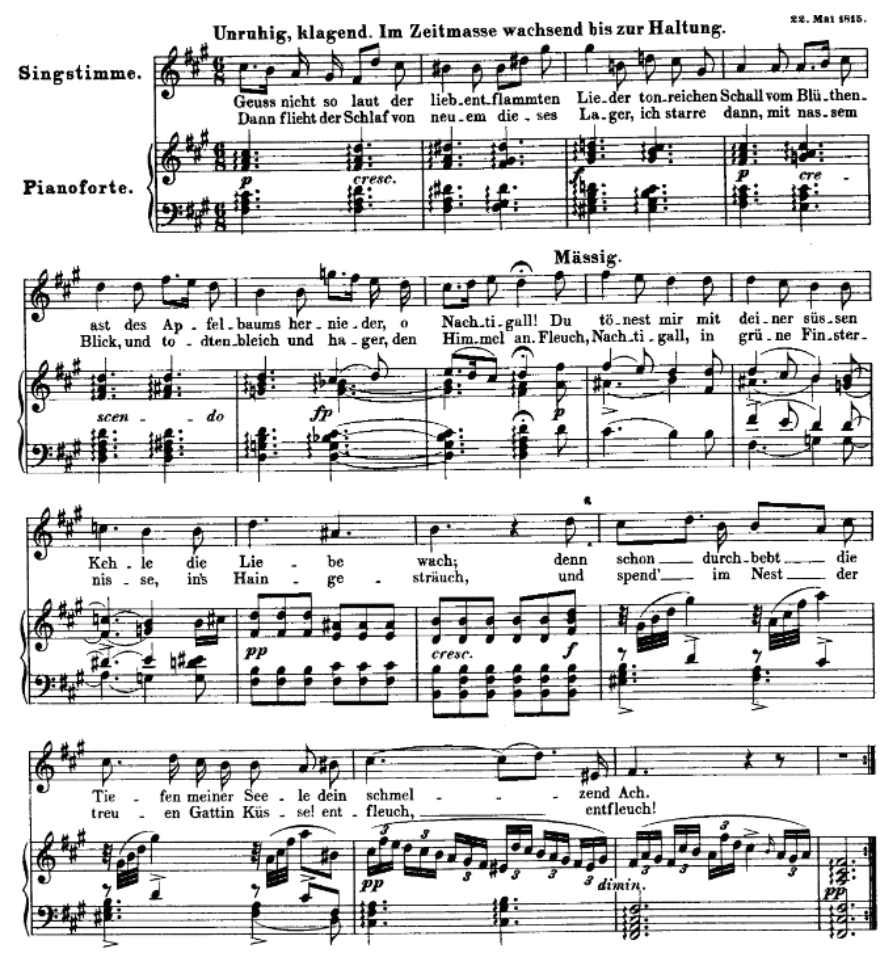

Example 13

The supplication to the nightingale in the first seven bars (stanza one) is presented by a vocal melody with punctuated rhythms and in increasing dynamics, complemented by distinct, arpeggiated chords in the piano. The melody that follows in the next ten measures (in piano dynamic), reflecting the speaker's emotions and state of mind, subtly undulates against the backdrop of a triplet accompaniment that sounds like a recollection of the nightingale's song (stanza two). 
Melancholy and sadness in stanza three contrast with the angry or impatient punctuated rhythms of the musical setting, while the anxious appeal of stanza four is set to a lyrical melody.

\section{Karol Szymanowski, The Nightingale}

An even more autonomous treatment of the music in relation to text can be found in Karol Szymanowski's song The Nightingale from the cycle Songs of a Fairytale Princess Op. 31 (24)

Methinks at times that God has by mistake

In place of heart enclosed a nightingale

In my breast. Silent by day, it wakes in the night

Sending its love song to the starry skies. Oh!

In the Polish original:

Ach! Zda mi się nieraz, że Bóg się pomylił

Miast serca zamknął w piersiach mych słowika,

Ach! Co milczy we dnie, a gdy noc nastanie,

Miłosną w gwiezdne niebo bije pieśnią. Ach!

This text, by the composer's sister Zofia, is used by Karol Szymanowski merely as a pretext or raw material for his musical setting, which reinforces the meanings suggested by the four-line poem, taking advantage of the listener's own knowledge and associations. The composer divides the song into seven segments, the first and last of which are respectively a seven-measure introduction and a symmetrically placed piano coda imitating birds' chirps. (Example 14) Segments two, four and six bring in the dramatic line of the nightingale's lament, set against a shimmering, sonoristic birdsong imitation devoid of tonal centres. (Example 15)

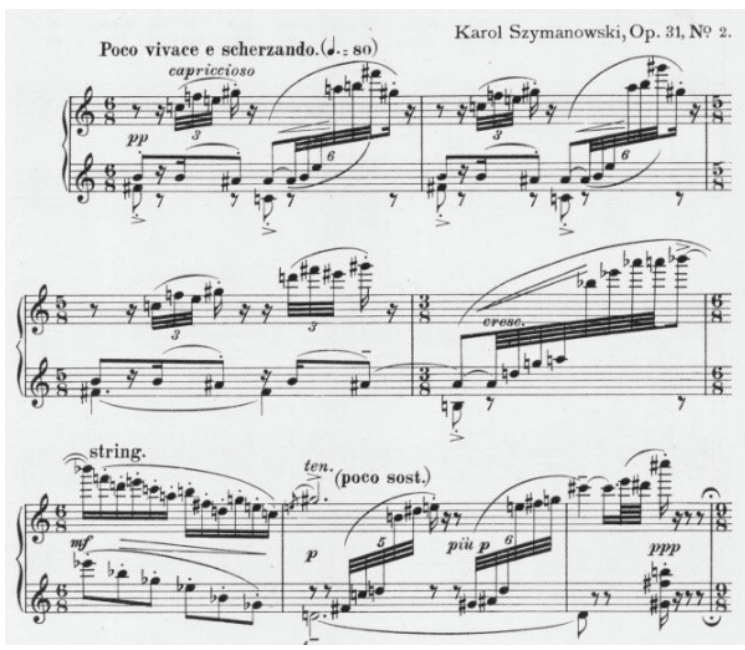




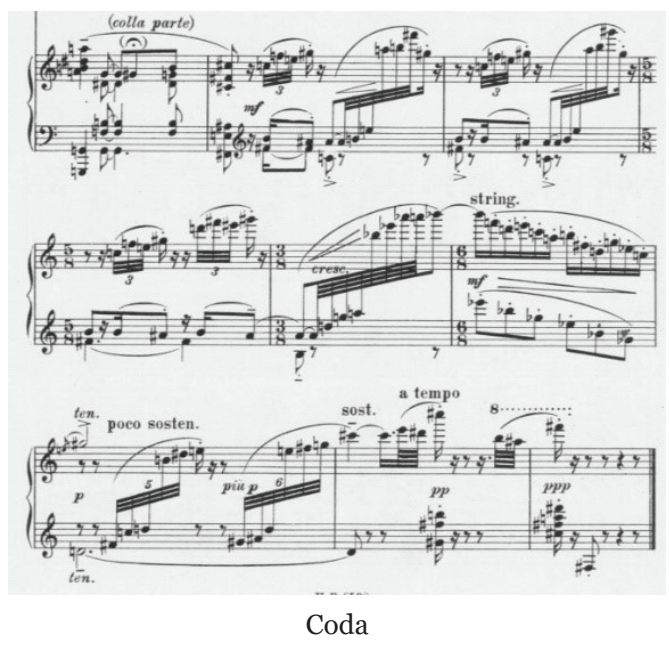

These dirges or laments are separated by two-line verse settings in segments three and five, but the text is inaudible or not very distinct. It has been blurred as a result of applying such 'topological' techniques as melismatic ornamentation of melody, sustained long rhythmic values that prolong individual words and make them incomprehensible.Verse 1: Dieu n'a pas mis un coeur dans mon sein jeunemais il y mit un rossignol bien sa. (Example 16) Verse 2: Il se tait le jour et la nuit venue appelle l'amour de sa voix radieuse. (Example 17)

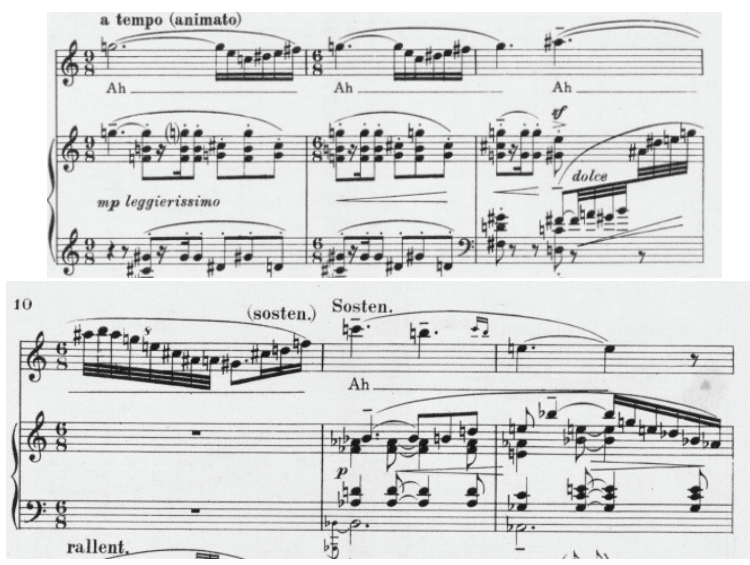

Example 15. Lament 1

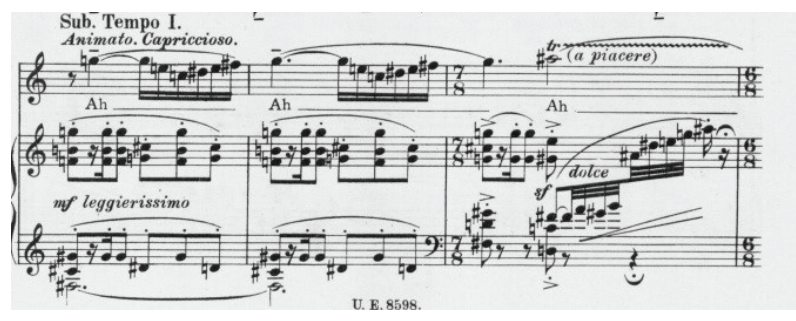




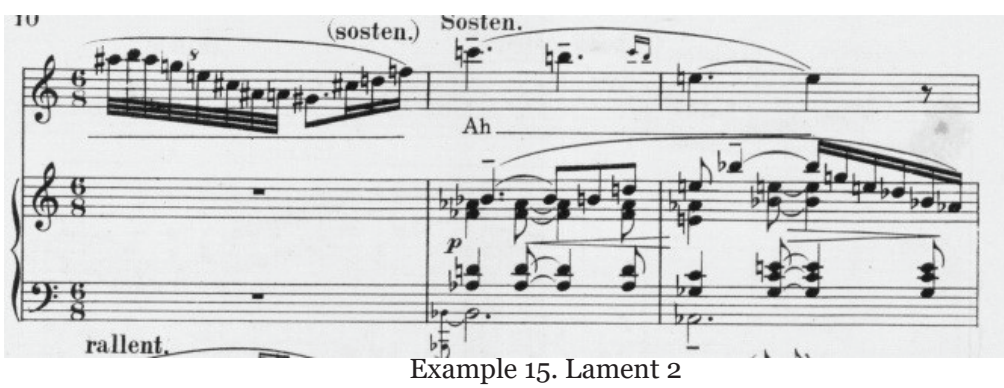

Sub. Tempo I

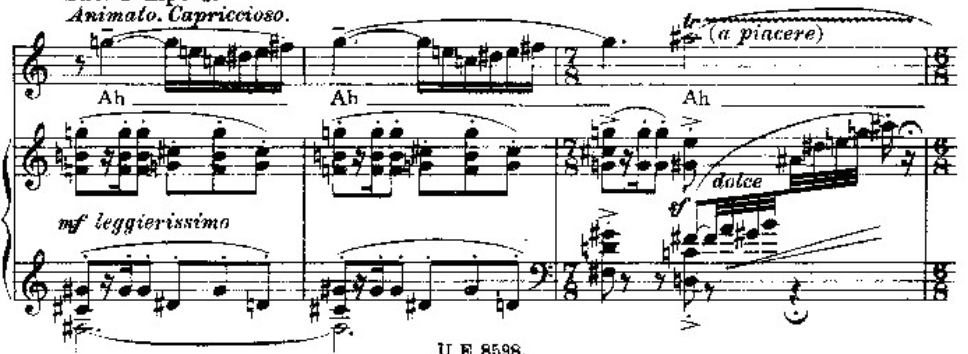

Example 15. Lament 3

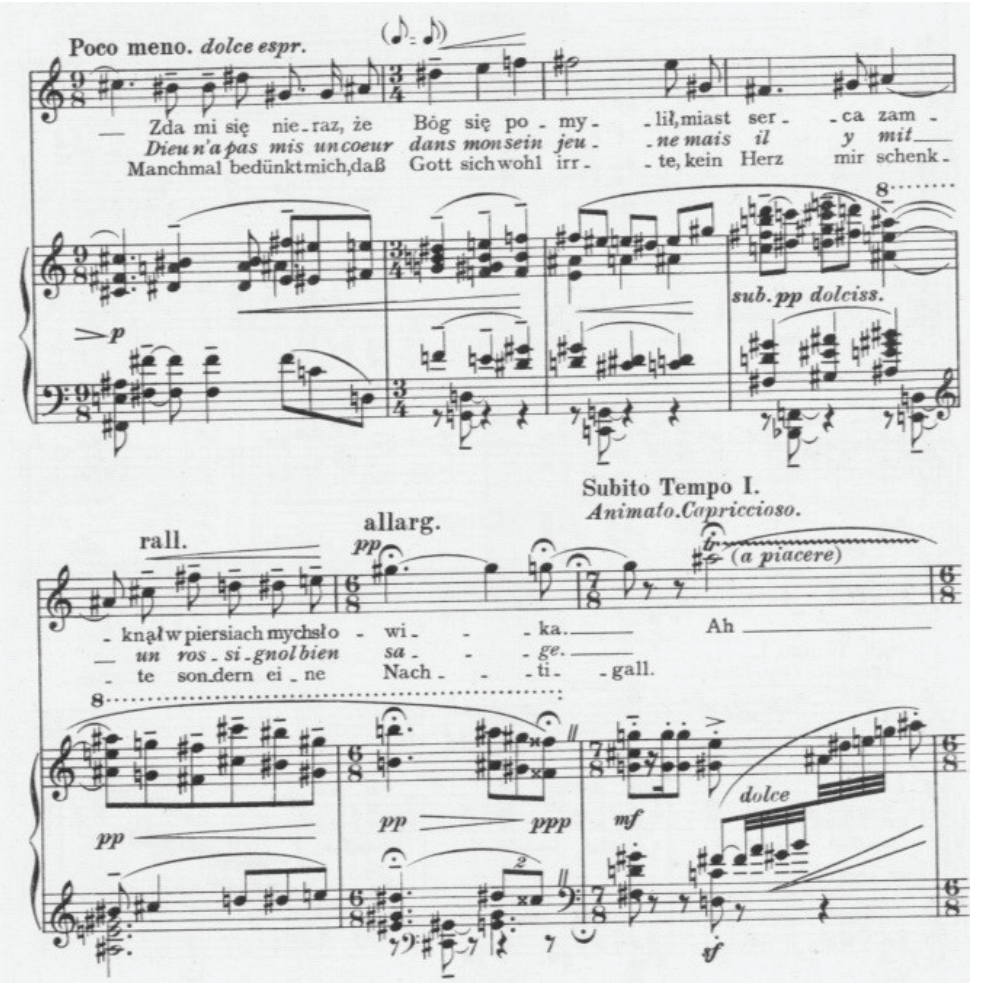



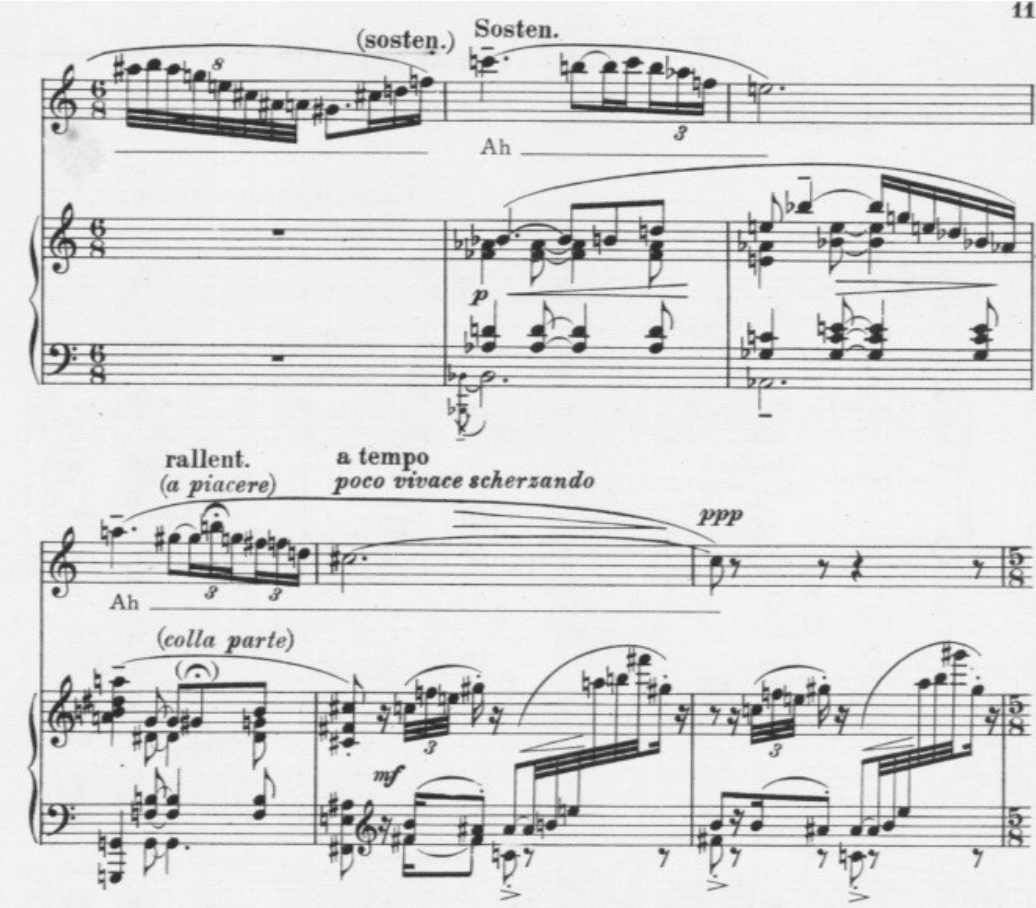

Example 16
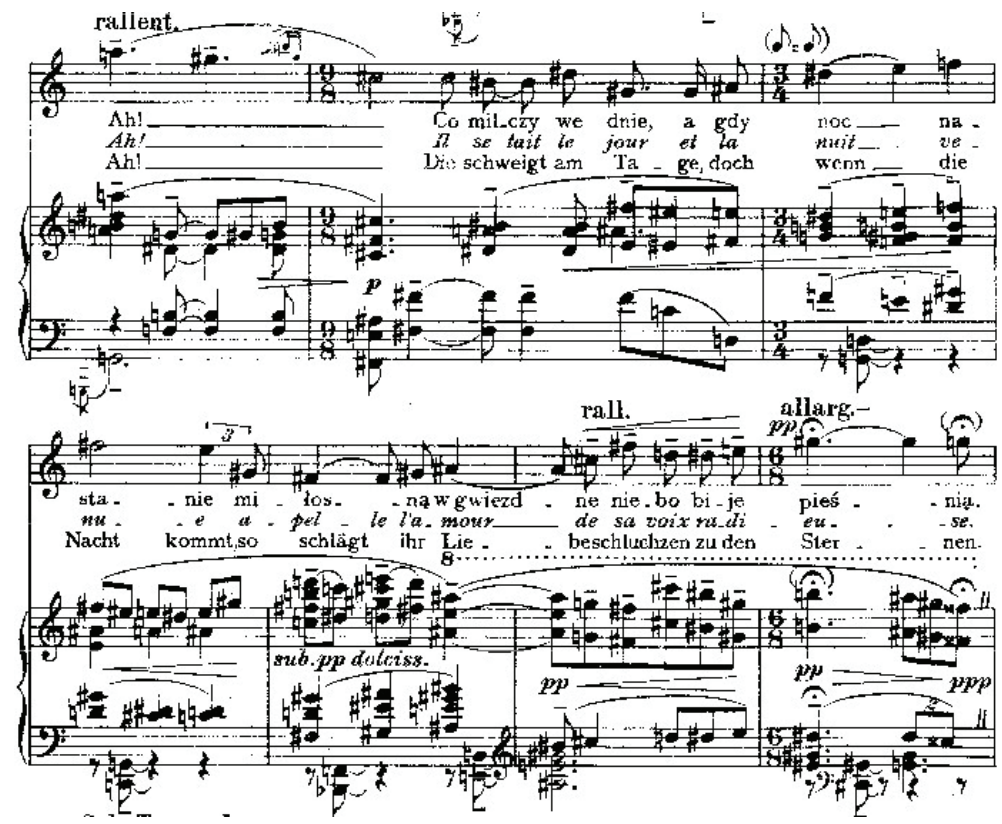

Example 17 
Importantly, the clear-cut if not schematic formal organisation of the Nightingale contrasts with the timbrally and rhythmically capricious quality of the piano part, which very aptly imitates the silvery sound of bird choruses characterised by barely definable pitch and irregular, complex rhythms. The time signatures constantly change to reflect the rhythmic patterns, as in the best, most complex birdsong imitations in the cycles by Olivier Messiaen.

\section{Conclusion}

Poems in which birds play an active role undeniably follow rhetorical models consciously adopted by the authors. For composers of Romantic songs, the ancient tales about birds, preserved in the form of semiotically marked poetic images, constituted highly promising material. Their semi-prefabricated linguistic forms, which modelled the expression and moods associated with a given bird, inspired the composers to look for parallel forms of musical expression for the same meanings and qualities. It remains an open question to what extent such parallels can be captured as regular, recurrent relations of musical gestures and motifs, which could be viewed as the musical equivalents of literary topoi. As I have demonstrated in my analyses, despite preserving all the fundamental elements of their mythic structure and landscape (death, love, song-lament, dark night, a tree), the nightingale songs differ in the distribution of textual accents and in the musical gestures they apply to express sadness, abandonment, longing, dream, mourning and love.

The rhetorical models used in poems set to music by Romantic composers were relaxed and diluted in the 2oth century. The poetic images of birds became much less distinctive, and their constituent set of motives - much impoverished. Relics of the old topoi have been disguised behind different forms of organisation of poetic utterance. If they do appear openly in the poem, it is as part of various verbal games or as allusions. This transformation is exemplified by Szymanowski's The Nightingale, which moves away from the original myth, though it does refer to all the deep-rooted images, beliefs, symbolic associations and musical gestures of the European culture tradition. The composer used these elements to create his own individual, well-known image of the nocturnal bird of love and death.

Birds are a highly specific subject for musicological research. On the one hand, we have the broad and fascinating problem of bird music as an element of musical discourse, which has been a source of meaning and a means of communication in the music of many different epochs. Leonard Ratner (in his Classic Music: Expression, Form, and Style) referred to such meaningful components in classical music as its topoi. The reception of birdsong mediated by poetry and musically represented in the art song presents the problem of musical meaning in a completely different light. The songs draw on meanings, symbolic associations and poetic metaphors which to a varying extent determine the corresponding models of musical expression. 


\section{References}

Armstrong, E. A. (1963). A Study of Bird Song. London: Oxford University Press.

Catchpole, C. K. \& Slater, P. J. B. (1995). Bird Song Biological Themes and Variations. London: Cambridge University Press.

Eliade, M. (1964). Shamanism. Archaic Techniques of Ecstasy. London: Routledge \& Kegan Paul.

Feld, S. (1990). Sound and Sentiment. Birds, Weeping, Poetics, and Song in Kaluli Expression. Philadelphia: University of Pennsylvania Press.

Kövecses, Z. (2005). Metaphor in Culture. Universality and Variation. London: Cambridge University Press.

Lévi-Strauss, C. (1962). La Pensée sauvage. Paris: Plon.

Lévi-Strauss, C. (1991). Totemism, trans. R. Needham. London: Merlin Press.

Pliny (transl. 1967). Natural History, (H. Rackman, Ed. and Trans.), vol. III. Cambridge: Harvard University Press.

Ratner, L. (1980). Classic Music: Expression, Form, and Style. London: Collier Macmillan Publisher. 